\title{
Nutrient cycling in a microflagellate food chain: I. Nitrogen dynamics*
}

\author{
Joel C. Goldman ${ }^{1}$, David A. Caron ${ }^{2}$, O. Ketil Andersen ${ }^{1 * *}$ \& Mark R. Dennett ${ }^{1}$ \\ ${ }^{1}$ Woods Hole Oceanographic Institution, Woods Hole, Massachusetts 02543, USA \\ ${ }^{2}$ Lamont-Doherty Geological Observatory, Palisades, New York 10964, USA
}

\begin{abstract}
In a series of grazing experiments we found that the phagotrophic microflagellate Paraphysomonas imperforata (Lucas) ( 7 to $12 \mu \mathrm{m} \mathrm{dia.)} \mathrm{fed} \mathrm{equally} \mathrm{well} \mathrm{on} \mathrm{the} \mathrm{diatom} \mathrm{Phaeodactylum}$ tricornutum and bacteria under batch conditions. Growth rates of the microflagellate were considerably higher than those of the phytoplankton prey. Regeneration of $\mathrm{NH}_{4}{ }^{+}$was negligible in control cultures of phytoplankton alone, bacteria alone, or phytoplankton and bacteria. However, when the microflagellate was grazing on either phytoplankton or bacteria there was considerable regeneration of $\mathrm{NH}_{4}{ }^{+}$This result was a clear indication that only the microflagellate was responsible for the excretion. Rates of $\mathrm{NH}_{4}{ }^{+}$excretion were highest during exponential growth of the microflagellate and slackened off considerably with onset of the stationary phase when growth of the prey was not nutrientlimited. Regeneration efficiencies, however, were lowest during exponential growth (15 to $30 \%$ ), but increased to $50 \%$ if calculated on the basis of the entire experiment which included the stationary phase. Regeneration efficiencies during exponential growth decreased to $8 \%$ when the prey was grown under nitrogen-limitation. Nitrogen turnover rates per body weight are generally much higher in microflagellates than in macrozooplankton, but can be greatly influenced by many environmental factors including prey nutritional state.
\end{abstract}

\section{INTRODUCTION}

The pathways by which inorganic nutrients are recycled in surface waters of the open ocean after the first step of phytoplankton assimilation are poorly understood. The classical view has been that nutrients are recycled in the euphotic zone by bacterial mineralization of both dead phytoplankton and phytoplankton excretion products and by direct grazing on phytoplankton by macrozooplankton. In recent years there has been considerable evidence that frequently the bulk of nutrient regeneration occurs among plankton less than $100 \mu \mathrm{m}$ in size (summarized in Harrison 1980) and in some cases by microbes smaller than $10 \mu m$ (Glibert 1982). Thus there is now some doubt that macrozooplankton grazing is an important process of nutrient regeneration in pelagic waters (Jackson 1980).

The role of bacteria in the nutrient regeneration

- Contribution No. 5863 from the Woods Hole Oceanographic Institution and 3835 from the Lamont-Doherty Geological Observatory

- Present address: Department of Biology, Marine Botany, University of Oslo, POB 1069, N-0316 Oslo 3, Norway process is equally confusing. Bacteria are efficient scavengers of inorganic nutrients; they have been shown, for example, to compete successfully with phytoplankton for inorganic phosphorus in numerous studies (Rhee 1972, Faust \& Correll 1976, Harrison et al. 1977). They also are very efficient in converting dissolved organic material (and presumably nutrients) to biomass (e.g. net growth yields between 50 and $70 \%$ are commonly observed) (Calow 1977). Hence, the contemporary notion is that direct excretion of inorganic nutrients during active growth of bacteria is not a major mode of remineralization (Williams 1981 . Joint \& Morris 1982, Hagstrom \& Larsson 1984). Additionally, bacterial hydrolysis of organic material from dead phytoplankton is probably minimal in the euphotic zone of pelagic waters for 2 reasons. First, the rate constants for such decomposition are known to be relatively low: 0.05 to $0.1 \mathrm{~d}^{-1}$ for the most labile fractions of phytoplankton biomass (Harrison 1980). Second, there is no evidence for spontaneous death of phytoplankton populations in the open sea - the remains of intact phytoplankton cells are not often found in oceanic surface waters (Pomeroy 1984). 
The resulting scenario is that bacteria are not efficient remineralizers of nutrients assimilated by growing phytoplankton and may even compete with phytoplankton for nutrients in the open ocean. This leaves the perplexing but unanswered question of how inorganic nutrients assimilated by phytoplankton and converted to particulate organic material are then recycled back into the dissolved phase. The importance of this question is dramatized by the possibility that 80 to $90+\%$ of nutrients in the euphotic zone of pelagic waters are recycled (Eppley \& Peterson 1979).

It has now become abundantly clear that phagotrophic microflagellates are the main grazers of bacteria in the sea (Haas \& Webb 1979, Fenchel 1982a, Azam et al. 1983, Davis \& Sieburth 1984, Sieburth 1984). Although, their role in recycling nutrients assimilated by bacteria has been the subject of some debate (Johannes 1965, Barsdate et al. 1974, Fenchel \& Harrison 1976), the importance of these voracious predators in this process now seems firmly established (Azam et al. 1983, Sherr et al. 1983).

Recently, one of us raised the possibility that phagotrophic microflagellates, being highly opportunistic, could play an important role in cropping both bacteria and phototrophs and in regenerating nutrients from all grazed microbes (Goldman 1984a,b). To test this hypothesis we performed a series of growth and nutrient regeneration studies under $\mathrm{NH}_{4}{ }^{+}, \mathrm{PO}_{4}^{-3}$, and non-nutrient-limited conditions on a heterotrophic microflagellate that we found capable of grazing on both bacteria and a variety of phytoplankton species. General features of our experimental results are reported elsewhere (Goldman \& Caron 1985). In this study we examine the details of nitrogen cycling by the microflagellate under the different nutritional conditions. In subsequent papers we report on population dynamics and carbon cycling (Caron et al. 1985) and on phosphorus cycling (Andersen et al. unpubl.).

\section{METHODS}

Microbial species. A heterotrophic microflagellate, identified as Paraphysomonas imperforata (Lucas) ( 7 to $12 \mu \mathrm{m}$ in diameter) (see Goldman \& Caron 1985), was isolated from a tidal channel connecting Vineyard Sound, Massachusetts with an estuarine pond near the Woods Hole Oceanographic Institution (WHOI). A clonal culture of the microflagellate was started from the second stage of a 2 -stage continuous culture system. The first stage was a culture of the marine diatom Phaeodactylum tricornutum (clone TFX-1) grown on synthetic seawater medium (Goldman \& McCarthy 1978). To start an enrichment culture in the second stage a few ml of a centrifuged concentrate of $35 \mu \mathrm{m}$ filtered seawater from the tidal channel was added and a diverse population of protozoa developed. The microflagellate, chosen because it grazed directly on the diatom, was then isolated and made bacteria-free by micropipetting individual cells into an axenic culture of $P$. tricornutum containing antibiotics. The microflagellate culture was maintained by making approximate weekly transfers to fresh cultures of $P$. tricornutum. Routine tests were made for bacterial contamination

The culture of Phaeodactylum tricornutum, used both to isolate the microflagellate and for the grazing and nutrient regeneration experiments, came from the culture collection of R. R. L. Guillard. Bacterial populations used in the grazing and regeneration experiments were either a mixed bacterial population grown on $0.8 \mu \mathrm{m}$ filtered (Nuclepore) seawater from Vineyard Sound enriched with $0.01 \%$ yeast extract, or a pure culture of Pseudomonas halodurans obtained from H. W. Jannasch at WHOI and maintained on nutrient seawater agar.

Experimental protocols. Three sets of experiments were performed, 1 at $24^{\circ} \mathrm{C}$ (Experiment $\mathrm{A}$ ) and the other 2 at $20^{\circ} \mathrm{C}$ (Experiments B \& C) (Table 1). Experiment $\mathrm{A}$ involved all possible combinations of the alga, bacteria (mixed population), and microflagellate plus control experiments with the alga and bacteria alone. It was intended to make the prey cultures $\mathrm{N}$-limited in Experiment $A$ by adjusting the $\mathrm{N}$ : $\mathrm{P}$ ratio of synthetic seawater media (Goldman \& McCarthy 1978) to 10 $\left(100 \mu \mathrm{g}\right.$-at $\mathrm{I}^{-1} \mathrm{NH}_{4}{ }^{+}$and $10 \mu \mathrm{g}$-at $\left.\mathrm{l}^{-1} \mathrm{PO}_{4}{ }^{-3}\right)$. However, as will be discussed in the 'Results' section, the grazing phase of the experiments was commenced while the phytoplankton or bacterial cultures were still in the exponential phases of growth; thus we did not attain clear-cut $N$-limited conditions. Experiment B was similar to Experiment $A$, but with the prey grown on a $\mathrm{P}$ limited growth medium with an $\mathrm{N}: \mathrm{P}$ ratio of 60 $\left(150 \mu \mathrm{g}\right.$-at $\mathrm{l}^{-1}$ of $\mathrm{NH}_{4}^{+}$and $2.5 \mu \mathrm{g}$-at $\mathrm{l}^{-1}$ of $\left.\mathrm{PO}_{4}^{-3}\right)$. Phosphorus or nitrogen limitation was ensured in the prey cultures (Phaeodactylum tricornutum and Pseudomonas halodurans) of Experiment $C$ by using the appropriate $\mathrm{N}$ : P ratios in the medium and allowing the cultures to enter the stationary phase before adding the microflagellate (Table 1).

All experiments were performed with $7 \mathrm{l}$ of media in 81 glass carboys, except for the bacterial control in Experiment A which was performed with $900 \mathrm{ml}$ of medium in a 11 flask. The bacterial medium was supplemented with $36 \mathrm{mg} 1^{-1}$ glucose. Sterile growth media were inoculated with either Phaeodactylum tricornutum or bacteria from stock cultures grown to late exponential phase in order to minimize carry-over of nutrients. The cultures were mixed with a magnetic stirring bar and with bubbled air (filter-sterilized). The 
Table 1. Summary of experimental conditions for grazing in the dark by the phagotrophic microflagellate Paraphysomonas imperforata on the marine diatom Phaeodactylum tricornutum and on bacteria

\begin{tabular}{|c|c|c|c|c|c|}
\hline $\begin{array}{c}\text { Experi- } \\
\text { ment }\end{array}$ & $\begin{array}{l}\text { Tempera- } \\
\text { ture }\left({ }^{\circ} \mathrm{C}\right)\end{array}$ & Microbes involved & $\begin{array}{l}\text { N:Pratio } \\
\text { in medium } \\
\text { (by atoms) }\end{array}$ & $\begin{array}{c}\text { Prey cell } \\
\text { quota } \\
\text { (pg N cell }{ }^{-1} \text { ) }\end{array}$ & $\begin{array}{c}\text { Microflagellate } \\
\mu \pm \mathrm{SE} \\
\left(\mathrm{d}^{-1}\right)\end{array}$ \\
\hline \multirow[t]{7}{*}{ A } & 24 & Diatom & $10: 1$ & 2.0 & - \\
\hline & & Bacteria & & 0.03 & - \\
\hline & & Bacteria $\cdots$ & & 0.02 & - \\
\hline & & Diatom + bacteria & & 2.5 & - \\
\hline & & Diatom + microflagellate & & 2.2 & $3.48 \pm 0.189$ \\
\hline & & Diatom + bacteria + microflagellate & & 2.0 & $3.41 \pm 0.225$ \\
\hline & & Bacteria ${ }^{\cdot}+$ microflagellate & & 0.03 & $3.50 \pm 0.221$ \\
\hline \multirow[t]{3}{*}{ B } & 20 & Diatom + bacteria $\cdots$ & $60: 1$ & 1.7 & - \\
\hline & & Diatom + microflagellate & & 1.5 & $2.55 \pm 0.199$ \\
\hline & & Diatom + bacteria $\cdots+$ microflagellate & & 1.3 & $2.52 \pm 0.021$ \\
\hline \multirow[t]{3}{*}{$\mathrm{C}$} & 20 & Bacteria $\cdots+$ microflagellate & $50: 1$ & 0.05 & $2.47 \pm 0.101$ \\
\hline & & Diatom + microflagellate & $60: 1$ & 1.0 & $2.10 \pm 0.075$ \\
\hline & & Diatom + microflagellate & $10: 1$ & 0.8 & $2.31 \pm 0.077$ \\
\hline $\begin{array}{l}\text { - Mixed b } \\
\text { - Pseudon }\end{array}$ & $\begin{array}{l}\text { erial popul } \\
\text { as halodur }\end{array}$ & & & & \\
\hline
\end{tabular}

experiments were performed in a walk-in incubator maintained on a $12 \mathrm{~h}$ light-12 h dark cycle. Air bubbling was stopped when the cultures reached designated points in the growth curves and inocula of the microflagellate and/or bacteria were added. Cultures were then darkened and time series measurements of a variety of biological and chemical parameters were made in approximate $6 \mathrm{~h}$ intervals over a 6 to $7 \mathrm{~d}$ period. Although a constant dark period is unrealistic, we wanted to avoid nutrient uptake and growth of $P$. tricornutum during grazing. Such a condition would have seriously complicated our attempts to calculate grazing and nutrient regeneration rates of the microflagellate.

Sampling was started within 8 h of placing the cultures in the dark. The bacterial inoculum added to the algal cultures came from the $7 \mathrm{l}$ bacterial culture and the microflagellate inoculum came from a stock culture grown on Phaeodactylum tricornutum. Aseptic sampling was done with a gravity fed siphon clamped at the end. Before each sampling a volume of liquid exceeding the volume of the siphon tube was wasted; approximately $400 \mathrm{ml}$ of culture were then collected and used for all analyses required in this study and in the companion studies of Caron et al. (1985) and Andersen et al. (unpubl.).

Analytical methods. Particulate nitrogen (PN) was measured with a Perkin Elmer 240 Elemental Analyzer on $25 \mathrm{mi}$ samples retained on pre-combusted Whatman $\mathrm{GF} / \mathrm{F}$ glass-fiber filters. Filtration pressure differentials were $25 \mathrm{~mm} \mathrm{Hg}$. Sufficient filtrate was collected to measure $\mathrm{NH}_{4}^{+}$(McCarthy \& Kamykowski 1972) and urea (McCarthy 1970) immediately and to freeze a portion for later analyses of $\mathrm{NO}_{3}{ }^{-}$(Wood et al. 1967). Cells of Phaeodactylum tricornutum were counted in Experiment $A$ with a Spencer Bright-line hemacytometer on samples preserved in Lugol's solution. Epifluorescence microscopy with acridine orange staining (Watson et al. 1977, Davis \& Sieburth 1982) was used to count bacteria and Paraphysomonas imperforata in Experiment $A$ and all microbes in Experiments $B$ and C. Samples were preserved in $1 \%$ glutaraldehyde in filtered seawater.

Data analyses. The microflagellate growth and grazing curves were divided into 5 convenient intervals to facilitate analyses and interpretation of the data. Interval I defined the portion of each growth curve where the initial decrease in prey cell number was so small that it was impossible to calculate a nitrogen ingestion or excretion rate. Interval II described the exponential phase of microflagellate growth which was concomitant with pronounced decreases in prey cell number and increases in $\mathrm{NH}_{4}{ }^{+}$excretion. Interval III was the transition phase between exponential growth and the stationary phase where both the rates of grazing and nitrogen excretion decreased markedly. Finally, Intervals IV and $V$ defined the early and late stationary phases, respectively. Each interval was designated by visual inspection of the experimental curves.

Specific growth rates $\mu\left(\mathrm{d}^{-1}\right)$ of the heterotrophic microflagellate were determined from linear regression analyses of the plots of the natural log of cell count versus time for the exponential phase of growth (Intervals I and II). Both the average nitrogen ingestion and 
excretion rates per microflagellate cell for each interval were determined by the expressions:

$$
I_{N}=Q_{N p}\left(P_{1}-P_{2}\right) \cdot(\bar{F} \cdot \Delta t)^{-1}
$$

and

$$
E_{N}=\left(\Sigma N_{2}-\Sigma N_{1}\right) \cdot(\bar{F} \cdot \Delta t)^{-1}
$$

where $\mathrm{I}_{N}$ and $E_{N}=$ nitrogen ingestion and excretion rates, respectively (pg $N$ cell $\left.^{-1} \mathrm{~d}^{-1}\right) ; \mathrm{Q}_{\mathrm{Np}}=$ nitrogen cell quota for Phaeodactylum tricornutum or bacteria at the time the microflagellate was introduced into the culture (pg $\mathrm{N}_{\text {cell }}{ }^{-1}$ ); $\mathrm{P}_{1}$ and $\mathrm{P}_{2}=$ prey cell concentration (cells $\mathrm{ml}^{-1}$ ) at the start and end, respectively, of each interval $\Delta t(d) ; \Sigma N_{2}$ and $\Sigma N_{1}=$ sum of excreted $\mathrm{NH}_{4}{ }^{+}$and urea at the end and beginning, respectively,

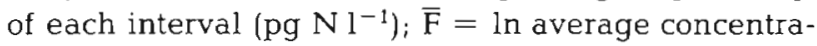
tion of microflagellates (cells $\mathrm{ml}^{-1}$ ) during each interval. The equation $\left(F_{2}-F_{1}\right) \cdot\left(\ln F_{2}-\ln F_{1}\right)^{-1}$ of Heinbokel (1978) was used to determine $\bar{F}$, where $F_{2}$ and $F_{1}=$ microflagellate cell number (cells $\mathrm{ml}^{-1}$ ) at the end and start respectively of each interval. Nitrogen regeneration efficiencies $\left(R_{N}\right.$ in \%) were calculated either as $\left(E_{N} \cdot I_{N}{ }^{-1}\right) \cdot 100$ for each interval or the sum of Intervals I to III or I to IV by the expression:

$$
\mathrm{R}_{\mathrm{N}}=\left[\left(\Sigma \mathrm{N}_{\mathrm{t}}-\Sigma \mathrm{N}_{\mathrm{O}}\right) \cdot P \mathrm{~N}_{\mathrm{O}}^{-1}\right] \cdot 100
$$

where $\Sigma \mathrm{N}_{\mathrm{O}}$ and $\mathrm{PN}_{\mathrm{O}}=$ concentrations of $\Sigma \mathrm{N}$ and particulate nitrogen respectively at the start of the dark phase; $\Sigma \mathrm{N}_{\mathrm{t}}=$ concentration of $\Sigma \mathrm{N}$ at the end of the designated summed interval.

Estimates of the microflagellate nitrogen cell quota at each sampling were made from the following expression:

$$
Q_{\mathrm{Nf}}=\left(P N_{t}-Q_{N p} P_{t}\right) \cdot F_{t}^{-1}
$$

where $Q_{N f}$ and $P N_{t}=$ flagellate nitrogen cell quota (pg
$\mathrm{N}$ cell $^{-1}$ ) and particulate nitrogen concentration respectively at each sampling; $P_{t}$ and $F_{t}=$ cell concentrations of the prey organisms and the microflagellate respectively at each sampling.

\section{RESULTS}

\section{Prey physiological state before grazing}

We found no evidence of $\mathrm{N}$ or $\mathrm{P}$ limitation in any of the prey cultures, except when purposely kept in the growth phase for an extended period (Experiment C). At the end of the growth phase of Experiment $A$ not only was there a slight residual of $\mathrm{NH}_{4}{ }^{+}$remaining in all cultures, but the particulate $\mathrm{C}: \mathrm{N}$ ratios (by atoms) were about 5 to 6 in the phytoplankton cultures and about 4 in the bacterial culture (data not shown). For the most part, any remaining $\mathrm{NH}_{4}{ }^{+}$in these experiments was rapidly consumed at the beginning of the dark phase with a concomitant rapid but small increase in phytoplankton or bacterial cell numbers (Fig. 1 to 3). When the phytoplankton and bacterial cultures were grown on medium with an $\mathrm{N}$ : P ratio of 50 to 60 (Experiments $\mathrm{B} \& \mathrm{C}$ ) there was a very large residual of $\mathrm{NH}_{4}{ }^{+}$at the end of the growth phase (Fig. 4 $D \& 5 \mathrm{C}$ ) and the particulate $\mathrm{N}: \mathrm{P}$ ratios were $<20$ (data not shown). In contrast, the particulate $\mathrm{N}: \mathrm{P}$ ratio rose to 23 to 30 in the P-limited cultures of Experiment C. Also, particulate alkaline phosphatase in these cultures was significantly higher than in any of the others (Anderson et al. unpubl.). The particulate $C: N$ ratio was about 9 in the $\mathrm{N}$-limited culture of Experiment $\mathrm{C}$ as opposed to ratios of 5 to 6 in the non-nutrientlimited cultures (data not shown).
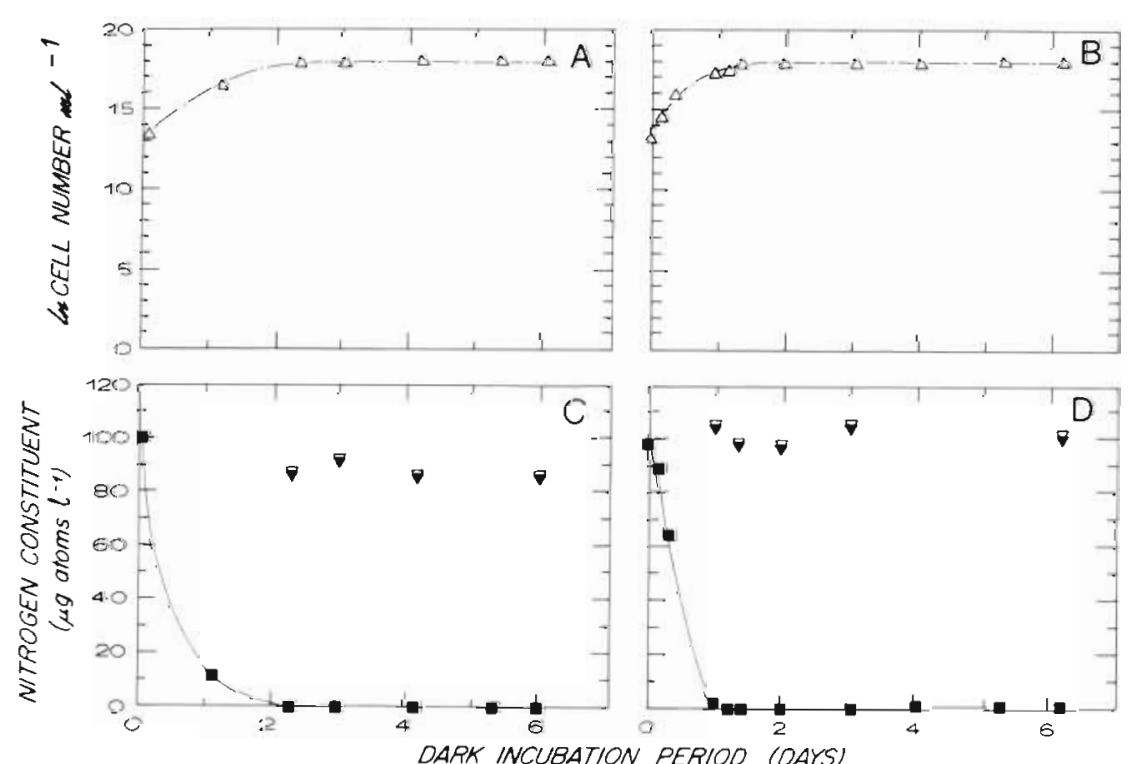

Fig. 1 Control bacterial experiments Cell number $(\Delta)$ of (A) Pseudomonas halodurans, (B) mixed bacterial assemblage, grown under non-nitrogen- and non-phosphorus-limiting conditions in the dark. Corresponding plots of nitrogen mass balance are shown in (C) $P$ halodurans, (D) mixed bacterial population. (-) $\Sigma \mathrm{N}$ (urea plus $\mathrm{NH}_{4}{ }^{+}$); ( $\mathbf{\nabla}$ ) particulate $\mathrm{N}_{i}(\nabla)$ total $\mathrm{N}$ (PN + urea + $\mathrm{NH}_{4}{ }^{+}$). Time zero indicates when initial bacterial inoculum was added to medium 
Fig. 2. Control phytoplankton experiments. Cell number ( $\square$ ) of Phaeodactylum tricornutum first grown under nonnutrient-limiting conditions (Experiment A) and then placed in the dark in (A) absence or $(B)$ presence of bacteria $(\Delta)$. Corresponding plots of nitrogen mass balance are shown in (C) without bacteria, (D) with bacteria. ( $\square) \Sigma N_{\text {; }}(\boldsymbol{\nabla})$ particulate $\mathrm{N}_{i}(\nabla)$ total $\mathrm{N}$. Time zero indicates when cultures had grown to mature populations. Same for Fig. 3 to 5

Fig. 3. Grazing of Phaeodactylum tricornutum ( $\square$ ) grown under non-nutrientlimiting conditions (Experiment A) by the phagotrophic microflagellate Paraphysomonas imperforata (•) in (A) absence or $(B)$ presence of bacteria $(\Delta)$. Intervals I to $V$ define intervals of grazing as described in text. Corresponding plots of nitrogen mass balance are shown in (C) without bacteria, (D) with bacteria.

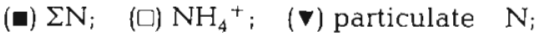
$(\nabla)$ total $N$
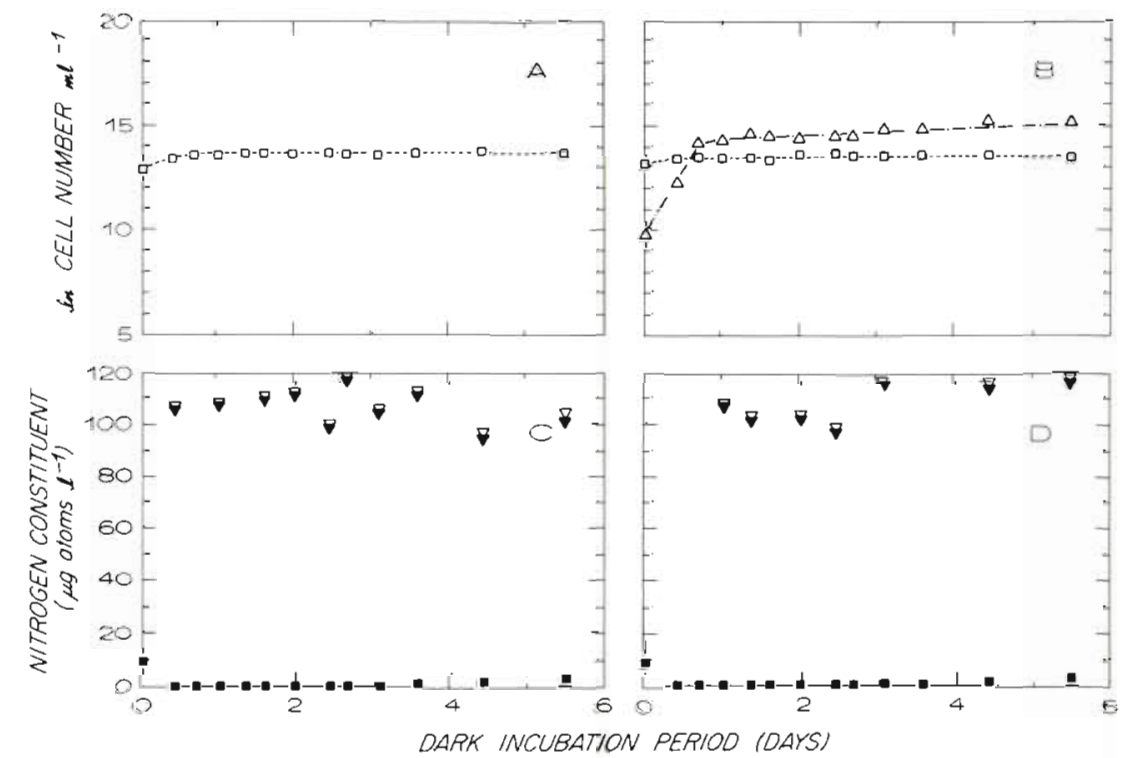

DARK INCUBATION PERIOO (DAYS)
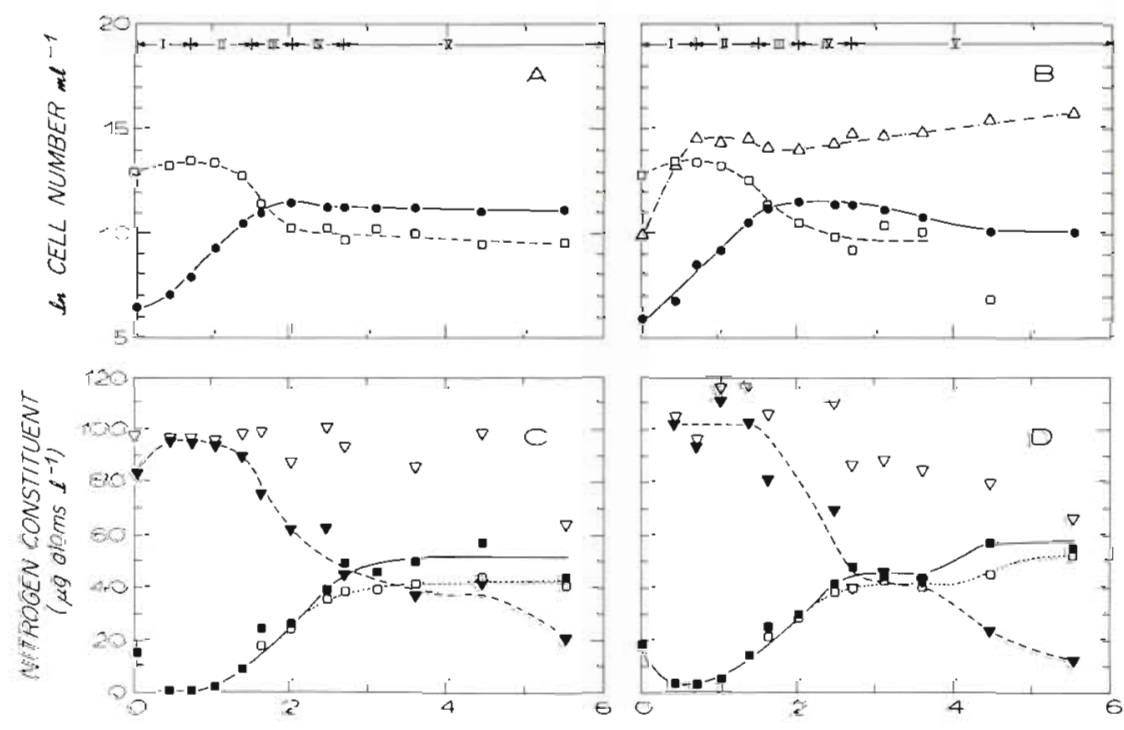

DARK INCUBATION PERIOD (OAYS)

\section{Phytoplankton and bacterial control experiments}

After the initial changes described above, we found no further changes over time in cell number or particulate nitrogen in the control cultures of Experiment $A$ consisting of a mixed bacterial population alone (Fig. 1B,D), Pseudomonas halodurans alone (Fig. 1A,C), or Phaeodactylum tricornutum either alone (Fig. 2A, C) or in combination with a mixed bacterial population (Fig. 2B, D). There was no evidence of $\mathrm{NH}_{4}{ }^{+}$or urea excretion in the bacterial control cultures during the course of the incubation (Fig. 1C, D), but there was a slight $\left(<3 \mu \mathrm{g}\right.$-at $\left.1^{-1}\right)$ build up of $\mathrm{NH}_{4}{ }^{+}$in the phytoplankton control cultures by Day 5.5 (Fig. 2C, D). We obtained similar results with the control incubations of
Experiment $\mathrm{B}$ involving $P$. tricornutum (medium $\mathrm{N}: \mathrm{P}$ ratio $=60$ ) plus bacteria, although in these experiments there were large residuals of $\mathrm{NH}_{4}{ }^{+}$remaining at the time the dark phase was started. Because all the results of Experiment $B$ were virtually identical to those of Experiment $A$, we have, with exception of growth rate data (Table 1), excluded them from presentation.

\section{Microflagellate grazing experiments}

There was a fairly consistent pattern of grazing by Paraphysomonas imperforata regardless of whether the prey was Phaeodactylum tricornutum only 

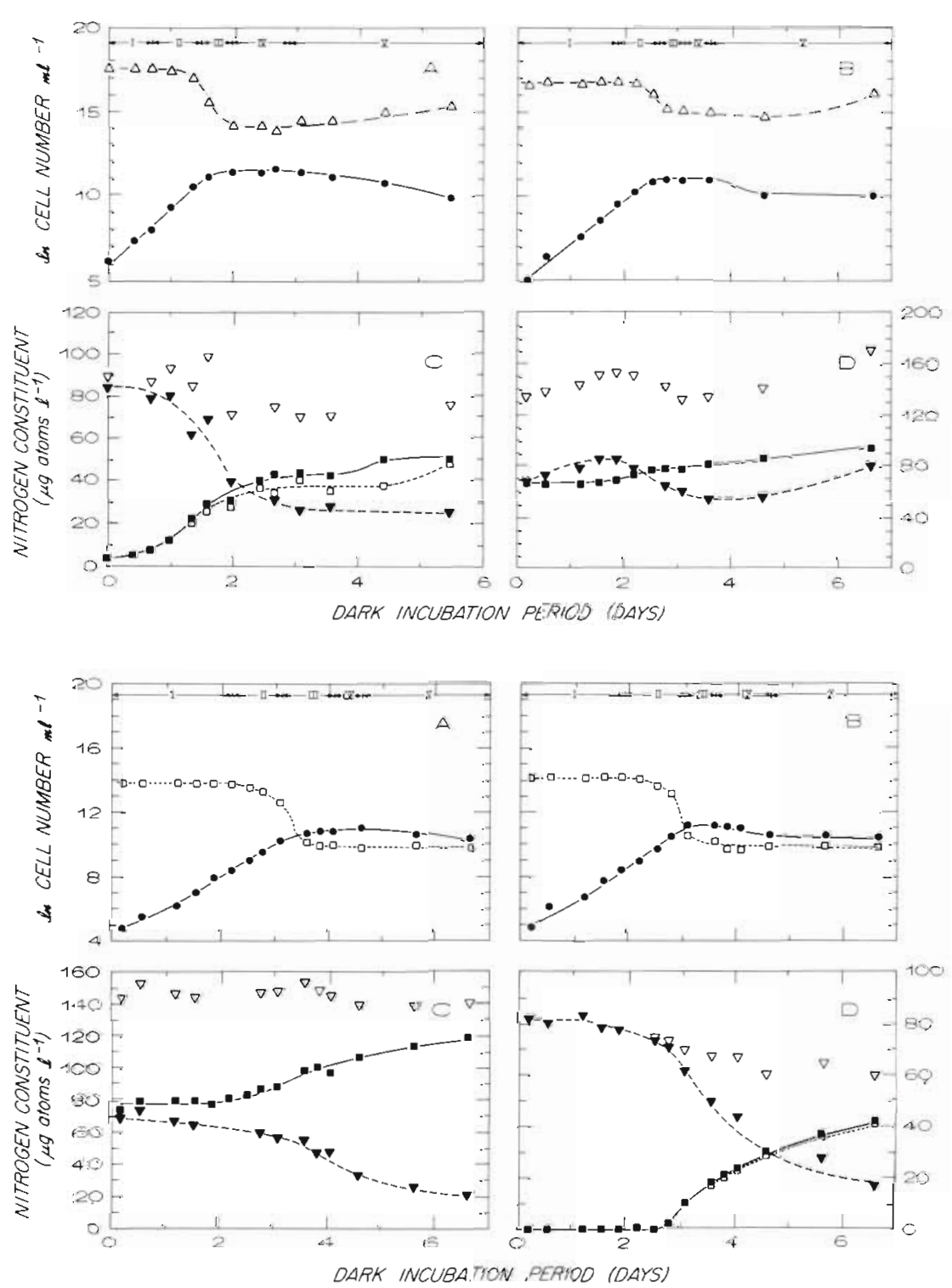

Fig. 4. Same as Fig. 3 except that prey are (A) a mixed bacterial assemblage (Experiment A) or (B) P-limited Pseudomonas halodurans (Experiment $B$ )

Fig. 5. Same as Fig. 3 except that prey are Phaeodactylum tricornutum that are (A) P-limited or (B) N-limited (Experiment C)

(Experiment A: Fig. 3A; Experiment C: Fig. 5A, B), P. tricornutum plus bacteria (Experiment A: Fig. 3B), or bacteria only (Experiments A \& C: Fig. 4A, B). Microflagellate numbers in each experiment increased exponentially for 1 to 2 d (Intervals I \& II) with corresponding reductions in prey population size. Transition from exponential growth to stationary phase (Interval III) always occurred rapidly. Prey threshold numbers corresponding to the onset of the stationary phase were about $10^{4}$ cells $\mathrm{ml}^{-1}$ for $P$. tricornutum (Fig. $3 \mathrm{~A}, \mathrm{~B}$ $\& 5 \mathrm{~A}, \mathrm{~B})$ and about 1 to $4 \times 10^{6}$ cells $\mathrm{ml}^{-1}$ for bacteria (Fig. 4A, B).

There was little change in cell numbers of both the microflagellate and Phaeodactylum tricornutum in the absence of bacteria after the stationary phase was reached (Intervals IV \& V) (Fig. 3A \& 5A, B). Visible aggregation of particulate material and wall growth developed, however, in all cultures containing the mixed bacterial assemblage (Fig. 3B \& 4A, B) during late stationary phase (Interval $V$ ). This aggregation was coincident with a general decrease in measured microflagellate numbers and an increase in bacterial numbers for the duration of the incubations. Similar wall growth and aggregation was not observed in cultures containing Pseudomonas halodurans.

\section{Nitrogen turnover and mass balance}

Peak values of the nitrogen ingestion rate of the microflagellate $\left(I_{N}\right)$ occurred during Interval II of Experiment A. Values of $I_{N}$ ranged from $80 \mathrm{pg} N$ cell-1 $\mathrm{d}^{-1}$ with only the alga present (based on curve in Fig. 3A) to $63 \mathrm{pg} \mathrm{N}$ cell ${ }^{-1} \mathrm{~d}^{-1}$ when bacteria were 


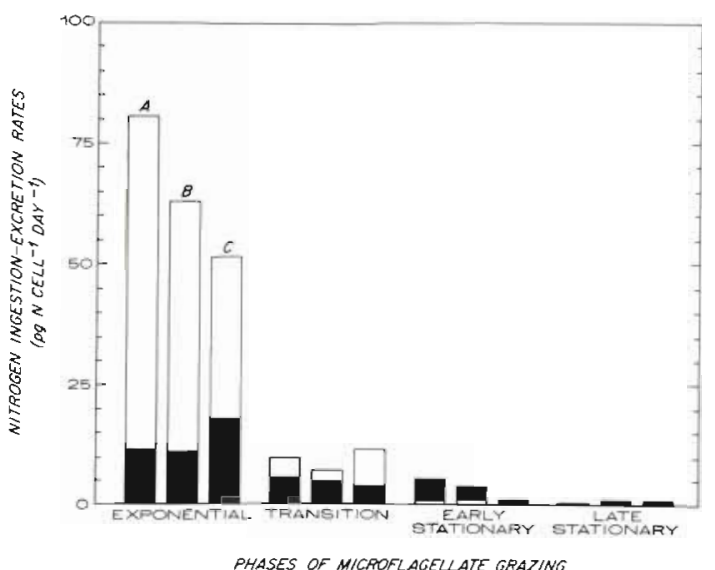

Fig. 6. Paraphysomonas imperforata. Rates of nitrogen ingestion (open bars) and excretion (solid bars) during different intervals of grazing on non-nutrient-limited cultures (Experiment A) of: Bar A: Phaeodactylum tricornutum without bacteria present; Bar B: P. tricornutum with bacteria present; Bar C: mixed bacteria alone

included with the alga (based on curve in Fig. 3B) and to $50 \mathrm{pg} \mathrm{N}$ cell ${ }^{-1} \mathrm{~d}^{-1}$ when only bacteria were present (based on curve in Fig. 3A) (Fig. 6). The nitrogen ingestion rate then dropped off dramatically in the transition stage in all 3 cultures and was negligible by the early stationary phase.

Ammonium excretion occurred concomitant with the onset of grazing in experiments where the prey were either not nutrient-limited (Fig. 3C,D \& 4C, D) or were P-limited (Fig. 5C). The rate of $\mathrm{NH}_{4}{ }^{+}$excretion per cell was fairly constant through the exponential growth phase (about 11 to $17 \mathrm{pg} \mathrm{N}$ cell ${ }^{-1} \mathrm{~d}^{-1}$ depending on the experiment) but then decreased through the transition and early stationary phases until excretion was negligible by late stationary phase (Fig. 6 \& 7). Urea excretion occurred during the transition or early stationary phases, but only in the cultures that were

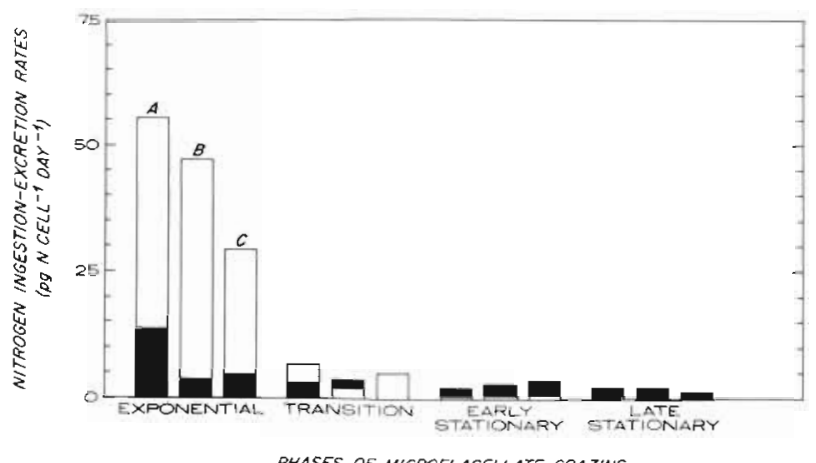

Fig. 7. Same as Fig. 6 except that Bar A: P-limited Phaeodactylum tricornutum; Bar B: N-limited $P$. tricornutum (Experiment C); Bar C: P-limited Pseudomonas halodurans (Experiment C) originally grown on media with an $\mathrm{N}$ : P ratio of 10 , and it never exceeded $15 \%$ of the total $N$ excreted (Fig. 3 $\mathrm{C}, \mathrm{D} \& 4 \mathrm{C}$ ). Ammonium excretion in the $\mathrm{N}$-limited culture of Experiment $C$ was delayed until the late exponential phase. A low but slowly decreasing excretion rate ( 4 to $2 \mathrm{pg} \mathrm{N}$ cells $\mathrm{s}^{-1} \mathrm{~d}^{-1}$ ) followed through the late stationary phase (Fig. 5D \& 7). Nitrate concentrations always were below detection limits $(<0.03 \mu \mathrm{g}$ at $\mathrm{l}^{-1}$ ).

Total $\mathrm{N}(\mathrm{PN}+\Sigma \mathrm{N})$ generally was conserved in all the experiments, at least through several days incubation: increases in $\Sigma \mathrm{N}$ were balanced by losses of $\mathrm{PN}$. We attributed losses in total $\mathrm{N}$ towards the end of particular experiments (e.g. Fig. 3D \& 4D) generally to bacterially-mediated aggregation and wall growth. Apparent losses of total $\mathrm{N}$ in the $\mathrm{N}$-limited culture not containing bacteria (Fig. 5D) are not easily explainable, but may have been due to insufficient mixing that led to some observed settling of particulate material.

The nitrogen cell quota $\left(\mathrm{Q}_{\mathrm{Np}}\right)$ for Phaeodactylum tricornutum under non nutrient-limited conditions ranged from 2.0 to $2.5 \mathrm{pg} \mathrm{N}$ cell-1 (Experiment $\mathrm{A}$ ) to 1.3 to $1.7 \mathrm{pg} \mathrm{N}$ cell ${ }^{-1}$ (Experiment B). Under P-limita-

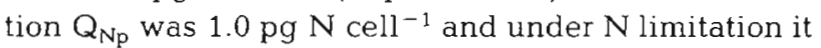
was $0.8 \mathrm{pg} \mathrm{N}$ cell $^{-1}$ (Experiment C) (Table 1). The nitrogen cell quota for bacteria was 0.02 to $0.03 \mathrm{pg} \mathrm{N}$ cell ${ }^{-1}$ in Experiment $\mathrm{A}$ and $0.05 \mathrm{pg} \mathrm{N}$ cell ${ }^{-1}$ in Experiment $C$ (Table 1). In calculating the nitrogen cell quota for the microflagellate $\left(Q_{\mathrm{Nf}}\right)$ we assumed that $Q_{N p}$ remained constant through each incubation period. During exponential growth (Interval II) $Q_{\mathrm{Nf}}$ was maximal at about 11 to $19 \mathrm{pg} \mathrm{N}$ cell-1, but then decreased to $<6$ to $8 \mathrm{pg} \mathrm{N}^{-1} \mathrm{Nell}^{-1}$ as the food supply became exhausted and starvation set in (Table 2). The magnitude of $Q_{N f}$ seemed not to be affected by the source or nutritional state of the prey.

\section{Nitrogen regeneration efficiency}

Total nitrogen excretion rates of the microflagellate $\left(E_{N}\right)$, as discussed previously, decreased during the course of the incubations, but at a much slower rate than the ingestion rate $\left(\mathbf{I}_{\mathrm{N}}\right)$. In fact, some excretion of $\Sigma \mathrm{N}$ continued through the stationary phase in each experiment, reflected in the diminishing value of $Q_{\mathrm{Nf}}$ (Table 2). However, because the magnitude of $E_{N}$ during exponential growth of the microflagellate was small relative to $I_{N}-$ only 5 to $10 \mathrm{pg} \mathrm{N}$ cell ${ }^{-1} \mathrm{~d}^{-1}$ (Fig. 6) - the actual efficiency of $N$ regeneration $\left(R_{N}\right)$ during this phase of growth was very low, varying from $14.5 \%$ when only Phaeodactylum tricornutum was the prey to $34 \%$ when only bacteria were grazed (Table 2). Although $R_{N}$ increased dramatically during each subsequent interval (Fig. 5; Table 2), total N 
Table 2. Paraphysomonas imperforata. Nitrogen cell quota $\left(Q_{\mathrm{N} 1}: \mathrm{pg} N\right.$ cell-1) and, in parentheses, nitrogen regeneration efficiency $\left(\mathrm{R}_{\mathrm{N}}\right.$ : \%) during different intervals of grazing

\begin{tabular}{|c|c|c|c|c|c|c|c|c|c|}
\hline \multirow{3}{*}{$\begin{array}{l}\text { Growth interval } \\
\text { II }\end{array}$} & \multirow{2}{*}{\multicolumn{3}{|c|}{$\begin{array}{c}\text { Experiment A } \\
\text { Diatom }+ \\
\text { Bacteria }\end{array}$}} & \multirow{2}{*}{\multicolumn{2}{|c|}{ Bacteria }} & \multirow{3}{*}{$\begin{array}{c}\text { Experiment B } \\
\text { Bacteria } \cdots \\
11 \quad \text { (17) }\end{array}$} & \multicolumn{3}{|c|}{ Experiment $\mathrm{C}$} \\
\hline & & & & & & & \multicolumn{2}{|c|}{$\begin{array}{l}\text { P-limited } \\
\text { diatom }\end{array}$} & $\begin{array}{c}\text { N-limited } \\
\text { diatom }\end{array}$ \\
\hline & 15 & (15) & (17) & 19 & (34) & & 17 & (24) & 13 \\
\hline III & 8 & (54) & (66) & 16 & (28) & $11 \quad(0)$ & 13 & $(56)$ & $9(>100)$ \\
\hline IV & & $>100)$ & $7(>100)$ & & $(100)$ & $9(>100)$ & & $>100)$ & $9(>100)$ \\
\hline V & & $>100)$ & $?(>100)$ & $?$ & $(100)$ & $?(>100)$ & & $>100\}$ & $6(>100)$ \\
\hline I-III $\cdots$ & & (24) & (30) & & $(30)$ & (8) & & (37) & (22) \\
\hline I-IV $\cdots$ & & (46) & (49) & & (41) & $(16)$ & & (46) & (37) \\
\hline \multicolumn{10}{|c|}{$\begin{array}{l}\text { - Mixed bacterial population } \\
\therefore \text { Pseudomonas halodurans } \\
\cdots\end{array}$} \\
\hline
\end{tabular}

regeneration through Interval IV never exceeded $49 \%$ of the initial prey nitrogen (as PN) that was present when the microflagellate was introduced (Table 2).

Patterns of $\mathrm{N}$ regeneration in all 3 experiments (Table 2) were, for the most part, virtually the same although absolute values of $I_{N}$ and $E_{N}$ in Experiment $B$ and $C$ were somewhat lower than in Experiment $A$. However, the delay in $\mathrm{N}$ excretion by the microflagellate when grazing on nitrogen-limited Phaeodactylum tricornutum (Fig. 5 B, D) led to a very low (8\%) regeneration efficiency during exponential growth (Table 2). Nonetheless, because $\Sigma N$ regeneration continued at a relatively high rate through the stationary phase (Fig. 5D \& 7), the summed $\Sigma N$ regeneration efficiencies in this experiment were comparable to those in the other incubations (Table 2).

\section{Microflagellate growth rates}

Specific growth rates $(\mu)$ of the microflagellate during Interval II appeared to be dependent on temperature during each set of experiments and not on the prey source or nutritional state: $\mu$ varied from 3.41 to $3.50 \mathrm{~d}^{-1}$ in Experiment $\mathrm{A}$ at $24^{\circ} \mathrm{C}$, to 2.10 to $2.55 \mathrm{~d}^{-1}$ in Experiments $\mathrm{B}$ and $\mathrm{C}$ at $20^{\circ} \mathrm{C}$ (Table 1).

\section{DISCUSSION}

\section{Nitrogen turnover by microflagellates}

As emphasized by Fenchel (1982a), there are important restrictions to studying grazing dynamics in batch cultures. Most important, balanced growth is never attained. Hence, it is extremely difficult to calculate grazing rates (and concomitantly, nutrient incorporation rates by the grazer) during exponential growth when predator and prey numbers are changing rapidly in opposite directions. In this study, estimates of nitrogen ingestion per microflagellate cell $\left(\mathrm{I}_{N}\right)$ during Interval II had to be based on subjective fits by eye of the curves of prey disappearance over a relatively short period when orders of magnitude decreases in prey occurred (see Fig. 3A,B). Thus for Interval II the differences in $I_{N}$ between experiments at a given temperature (Fig. 6 \& 7) probably were due as much to subjective errors in curve fitting by eye as they were to any real physiological differences resulting from the different experimental treatments. The generally higher values of $I_{N}$ at $24{ }^{\circ} \mathrm{C}-52$ to $81 \mathrm{pg} \mathrm{N}$ cell ${ }^{-1} \mathrm{~d}^{-1}$ (Fig. 6) than at $20^{\circ} \mathrm{C}-28$ to $55 \mathrm{pg} \mathrm{N}$ cell ${ }^{-1} \mathrm{~d}^{-1}$ (Fig. 7) - most likely were related to differences in growth rate which clearly were temperature-dependent.

In spite of the difficulty in accurately estimating $I_{N}$. our results show unequivocally that, relative to bacterial and phytoplankton activity, the bulk of $\mathrm{NH}_{4}{ }^{+}$ regeneration was performed by Paraphysomonas imperforata. A complicating factor in previous experiments on comparative nutrient regeneration by bacteria and protozoa has been the difficulty in separating the contribution of each microbial component when bacteria were the sole prey (Johannes 1965, Barsdate et al. 1974). In our study, because phytoplankton and bacteria both were prey, we were able to measure regeneration of nitrogen from grazed phytoplankton in the absence and presence of bacteria (Fig. 3C, D). Under these conditions we saw no appreciable difference in both the excretion rate per microflagellate during exponential growth and the pattem of regeneration over the full incubation period between the 2 
microbial systems (Fig. 6). The lack of nitrogen regeneration in the bacterial control cultures (Fig. 1C, D) and the small release of $\mathrm{NH}_{4}{ }^{+}$by Phaeodactylum tricornutum only during late stationary phase (Fig. 2C, D) is clear confirmation that the microflagellate solely was responsible for the net excretion of nitrogen we observed.

Still another indication that bacteria played no role in the regeneration of nitrogen is that the rate of $\mathrm{NH}_{4}{ }^{+}$ regeneration in the culture containing the microflagellate grazing only on bacteria was comparable to that when the prey was Phaeodactylum tricornutum (Fig. 6 \& 7). Cryptic growth of bacteria occurred once the microflagellate entered the stationary phase (Interval V), most likely on excreted organic carbon (see Caron et al. 1985), both when bacteria were added to the culture of P. tricornutum (Fig. 3 B) and when bacteria were the sole prey (Fig. 4A, B). This bacterial growth occurred without any concomitant increase in nitrogen regeneration above that found in the culture containing only $P$. tricornutum as the prey. From these results it would appear that regeneration of $\mathrm{NH}_{4}{ }^{+}$also was minimal during active bacterial growth, a conclusion consistent with the contemporary view that bacteria are consumers rather than regenerators of nutrients (Williams 1981, Azam et al. 1983, Hagstrom \& Larsson 1984). Overall, our findings are in line with the view of Johannes (1965) and Pomeroy (1984) that protozoa rather than bacteria are the main regenerators of nutrients at the microbial level, at least in systems in which primary productivity is in reasonable balance with grazing (e.g. pelagic surface waters).

It is not surprising that $\mathrm{NH}_{4}{ }^{+}$was the main excretory product of the microflagellate since marinezooplankton and protozoa are considered to be primarily ammonotelic (Stout 1980, Bidigare 1983). Similarly, our finding that urea excretion was about $15 \%$ of $\Sigma N$ excreted is consistent with contemporary evidence that urea is a secondary nitrogenous excretion product of macrozooplankton. Although the magnitude of urea excretion is variable, typically it constitutes about 10 to $20 \%$ of the nitrogen excreted by marine zooplankton (Bidigare 1983). Amino acids also can contribute 10 to $15 \%$ of excreted $\mathrm{N}$ in macrozooplankton (Bidigare 1983). In our study it was possible to achieve closure of our nitrogen mass balance by summing only $\mathrm{NH}_{4}{ }^{+}$, urea and $\mathrm{PN}_{\text {; }}$ thus excretion of amino acids must have occurred at very low levels, if at all. Anderssen et al. (1985), in fact, found that of the bacterial nitrogen ingested by bacterivorous microflagellates, only $0.02 \%$ was excreted as amino acids, principally serine, aspartic acid, glutamic acid, and ornithine. Other potential N excretion products such as purines (Soldo et al. 1978) would likewise be undetectable by our mass balance approach.

\section{Nitrogen regeneration efficiency}

Our second major finding was that during exponential growth (Interval II) the microflagellate was extremely efficient in conserving not only nitrogen (the regeneration efficiency for nitrogen was only about 15 to $25 \%$ when the prey food was not nutrient-limited), but also phosphorus (Andersen et al. unpubl.) and carbon (Caron et al. 1985). These results are comparable to those of Anderssen et al. (1985), who found a nitrogen regeneration efficiency $\left(R_{N}\right)$ of $13 \%$ when bacteria were consumed by microflagellates. The ability to conserve considerable nitrogen even when the food source is exhausted $\left(R_{N}\right.$ over Intervals I to IV never exceeded $50 \%$ ) raises important questions about how nutrients are cycled in the microbial food chain.

Ammonium regeneration rates for Paraphysomonas imperforata, when normalized on a per unit dry weight basis, are comparable to those obtained for several other microflagellates grazing on bacteria and are considerably higher than those reported for at least one large ciliate and numerous macrozooplankton species (Table 3). As seen from our own study (Fig. 6 \& 7), and also from the companion study on phosphorus dynamics (Andersen et al. unpubl.), the nitrogen and phosphorus regeneration rates for a given species can vary greatly depending on environmental factors such as temperature, predator nutritional state, and quality of the prey food. Thus, while we agree with the conclusion of Johannes (1964) that small protozoa have a much higher nutrient turnover potential per unit of body nutrient than macrozooplankton, we caution that for a given species these rates, like respiration rates (Fenchel \& Finlay 1983, Caron et al. 1985), can be highly variable.

Virtually nothing is known of the nutritional requirements and metabolic patterns of food digestion in phagotrophic microflagellates. From a physiological standpoint it is difficult to explain why there was a lag in $\mathrm{NH}_{4}{ }^{+}$excretion (Fig. 5D), but not phosphorus release (Andersen et al. in prep.) only when the phytoplankton food was N-limited. A similar retention of phosphorus, but not $\mathrm{NH}_{4}{ }^{+}$, occurred under P-limiting conditions (Andersen et al. unpubl.). Most likely, there are fairly rigid stoichiometric nutrient requirements of the microflagellatte while growing exponentially. Thus when there is an imbalance in the N:P ratio of the food ration the nutrient in shortest supply (in this case nitrogen) seems to be greatly conserved until exhaustion of the available food. Under N-limiting conditions synthesis of protein must dominate over the catabolic process of amino acid transamination and concomitant $\mathrm{NH}_{4}{ }^{+}$excretion. Just how this process is regulated biochemically is poorly understood. Conceivably, synthesis of GDH (glutamate dehydrogen- 


\section{LITERATURE CITED}

Anderssen, A., Lee, C., Azam, F., Hagstrom, A. (1985). Release of amino acids by heterotrophic marine microflagellates. Mar. Ecol. Prog. Ser. 23: 99-106

Azam, F., Fenchel, T., Field, J. G., Meyer-Reil, L. A., Thingstad, F. (1983). The ecological role of water-column microbes in the sea. Mar Ecol. Prog. Ser 10: 257-263

Barsdate, R. J., Prentki, R. T., Fenchel, I (1974). Phosphorus cycle of model ecosystems: significance for decomposer food chains and effect of bacterial grazers. Oikos 25: 239-251

Bidigare, R. R. (1983). Nitrogen excretion by marine zooplankton. In: Carpenter, E. J., Capone, D. C. (ed.) Nitrogen in the marine environment. Academic Press, New York, p. $385-409$

Bidigare, R. R., King, F. D. (1981). The measurement of glutamate dehydrogenase activity in Praunus flexuosus and its role in ammonium excretion. Comp. Biochem. Physiol. 70 B: $409-413$

Calow, P. (1977). Conversion efficiencies in heterotrophic organisms. Biol. Rev. 52: 385-409

Caron, D. A. (1984). The role of heterotrophic microflagellates in planktonic communities. Ph. D. thesis, Woods Hole Oceanogr. Inst. and Mass. Inst. Tech. p. 1-268

Caron, D. A., Goldman, J. L., Andersen, O. K., Dennett, M. R. (1985). Nutrient cycling in a microflagellate food chain: II. Population dynamics and carbon cycling. Mar. Ecol. Prog. Ser. 24: 243-254

Davis, P. G., Sieburth, J. McN. (1982). Differentiation of phototrophic and heterotrophic nanoplankton populations in marine waters by epifluorescence microscopy. Annls Inst. Oceanogr., Păris 58(S): 249-260

Davis, P. G., Sieburth, J. McN. (1984). Estuarine and oceanic microflagellate predation of actively growing bacteria: estimation by frequency of dividing-divided bacteria. Mar. Ecol. Prog. Ser. 19: 237-246

Debs, C. Abou (1984). Carbon and nitrogen budget of the calanoid copepod Temora stylifera: effect of concentration and composition of food. Mar. Ecol. Prog. Ser. 15: 213-223

Eppley, R. W., Peterson, B. J. (1979). Particulate organic matter flux and planktonic new production in the deep ocean. Nature, Lond. 282: 677-680

Faust, M. A., Correll, D. L. (1976). Comparison of bacterial and algal utilization of orthophosphate in an estuarine environment. Mar. Biol. 34: 151-162

Fenchel, T. (1982a). Ecology of heterotrophic microflagellates. II. Bioenergetics and growth. Mar. Ecol. Prog. Ser. 8: 225-231

Fenchel, T. (1982b). Ecology of heterotrophic microflagellates. III. Adaptations to heterogeneous environments. Mar. Ecol. Prog. Ser. 9: 25-33

Fenchel, T., Finlay, B. J. (1983). Respiration rates in heterotrophic, free-living protozoa. Microb. Ecol. 9: 99-122

Fenchel, T., Harrison, P. (1976). The significance of bacterial grazing and mineral cycling for the decomposition of particulate detritus. In: Anderson, J. M., Macfadyen, A. (ed.) The role of terrestial and aquatic organisms in decomposition processes. Blackwell Scientific Publ., Oxford, p. 285-299

Gardner, W. S., Paffenhöfer, G. A. (1982). Nitrogen regeneration by the subtropical marine copepod Eucalanus pileatus. J. Plankton Res. 4: 725-734

Gast, V., Horstmann, U. (1983). N-remineralization of phytoand bacterioplankton by the marine ciliate Euplotes vannus. Mar. Ecol. Prog. Ser. 13: 55-60

George, R. Y., Fields, J. R. (1984). Ammonia excretion in the antarctic krill Euphausia superba in relation to starvation and ontogenetic stages. J. Crust. Biol. 4 (Spec. No. 1): 263-272

Glibert, P. M. (1982). Regional studies of daily, seasonal, and size fraction variability in ammonium reminerization. Mar. Biol. 70: 209-222

Goldman, J. C. (1984a). Oceanic nutrient cycles. In: Fasham, M. J. (ed.) Flows of energy and materials in marine ecosystems: theory and practice. Plenum press, New York, p. $137-170$

Goldman, J. C. (1984b). Conceptual role for microaggregates. Bull. mar Sci. 35: 462-476

Goldman, J. C., Caron, D. A. (1985). Experimental studies on an omniverous microflagellate: Implications for grazing and nutrient regeneration in the marine microbial food chain. Deep Sea Res. 32: in press

Goldman, J. C., McCarthy, J. J. (1978). Steady state growth and ammonium uptake of a fast-growing marine diatom. Limnol. Oceanogr. 23: 695-703

Haas, L. W., Webb, K. L. (1979). Nutritional mode of several non-pigmented microflagellates from the York River Estuагу, Virginia. J. exp. mar. Biol. Ecol. 39: 125-134

Hagstrom, A., Larsson, U. (1984). Diel and seasonal variation in growth rates of pelagic bacteria. In: Hobbie, J. E., Williams, P. J. LeB. (ed.) Heterotrophic activity in the sea. Plenum Press, New York, p. 249-262

Harris, R. P. (1973). Feeding, growth, reproduction, and nitrogen utilization by the harpacticoid copepod Tigriopus brevicornis. J. mar. biol. Ass. U. K. 35: 785-800

Harrison, W. G. (1980). Nutrient regeneration and primary production in the sea. In: Falkowski, P. G. (ed.) Primary productivity in the sea. Plenum Press, New York, p. $433-460$

Harrison, W. G., Azam, F., Renger, E. H., Eppley, R. W. (1977). Some experiments on phosphate assimilation by coastal marine phytoplankton. Mar. Biol. 40: 9-18

Heinbokel, J. F. (1978). Studies on the functional role of tintinnids in the Southern California Bight. I. Grazing and growth rates in laboratory cultures. Mar. Biol. 47: 177-189

Hirche, H.-J. (1983). Excretion and respiration of the antarctic krill Euphausia superba. Polar Biol. 1: 205-209

Ikeda, T. (1974). Nutritional ecology of marine zooplankton Mem. Fac. Fish. Hokkaido Univ. 22: 1-97

Ikeda, T., Hing Fay, E., Hutchinson, S. A., Boto, G. M. (1982). Ammonia and inorganic phosphate excretion by zooplankton from inshore waters of the Great Barrier Reef, Queensland. I. Relationship between excretion rates and body size. Aust. J. mar. Freshwat. Res. 33: 55-70

Jackson, G. A. (1980). Phytoplankton growth and zooplankton grazing in oligotrophic oceans. Nature, Lond. 284: 439-441

Jenkins, W. J., Goldman, J. C. (1985). Seasonal oxygen cycling and primary productivity in the Sargasso Sea. J. mar. Res. 43: 465-491

Johannes, R. E. (1964). Phosphorus excretion as related to body size in marine animals: the significance of nannozooplankton in nutrient regeneration. Science 146 : 923-924

Johannes, R. E. (1965). Influence of marine protozoa on nutrient regeneration. Limnol. Oceanogr. 10: 434-442

Joint, I. R., Morris, R. J. (1982). The Iole of bacteria in the tumover of organic matter in the sea. Oceanogr. mar. Biol. A. Rev. 20: 65-118

Mayzaud, P. (1973). Respiration and nitrogen excretion of zooplankton. II. Studies of the metabolic characteristics of starved animals. Mar. Biol. 21: 19-28 
McCarthy, J. J. (1970). A urease method for urea in seawater. Limnol. Oceanogr. 15: 309-313

McCarthy, J. J., Kamykowski, D. (1972). Urea and other nitrogenous nutrients in La Jolla Bay during February, March, April, 1970. Fish. Bull. U.S. 70: 1261-1274

Pomeroy, L. R. (1984). Microbial processes in the sea: diversity in nature and science. In: Hobbie, J. E., Williams, P. J. LeB. (ed.) Heterotrophic activity in the sea. Plenum Press, New York, p. 1-23

Rhee, G. Y. (1972). Competition between an alga and an aquatic bacterium for phosphate. Limnol. Oceanogr. 17: $505-514$

Sherr, B. F., Sherr, E. B., Berman, T. (1983). Grazing, growth, and ammonium excretion rates of a heterotrophic microflagellate fed with four species of bacteria. Appl. environ. Microbiol. 45: 1196-1201

Sieburth. J. McN. (1984). Protozoan bactivory in pelagic marine waters. In: Hobbie, J. E., Williams, P. J. LeB. (ed.) Heterotrophic activity in the sea. Plenum Press, New York, p. $405-444$
Smith, S. L., Whitledge, T. E. (1977). The role of zooplankton in the regeneration of nitrogen in a coastal upwelling system off northwest Africa. Deep Sea Res. 24: 49-56

Soldo, A. T., Godoy, G. A., Larin, F. (1978). Purine-excretory nature of refractile bodies in the marine ciliate Parauronema acutum. J. Protozool. 25: 416-418

Stout, J. D. (1980). The role of protozoa in nutrient cycling and energy flow. Adv. Microb. Ecol. 4: 1-50

Watson, S. W., Novitsky, T. J., Quinby, H. L., Valois, F. W. (1977). Determination of bacterial number and biomass in the marine environment. Appl. environ. Microbiol. 33: 940-946

Williams, P. J. LeB. (1981). Incorporation of microheterotrophic processes into the classical paradigm of the planktonic food web. Kieler Meeresforsch. (Sonderh.) 5: 1-28

Wood, E. D., Armstrong, F. A. J., Richards, F. A. (1967). Determination of nitrate in seawater by cadmium-copper reduction to nitrite. J. mar. biol. Ass. U. K. 47: 23-31

This paper was presented by Professor P. J. Wangersky; it was accepted for printing on May 10, 1985 